\title{
NTROEN BALANCE IN AN INTENSIVELY UTILISED DAIRYFARM SYSTEM
}

T. R. 0. FIELD and P. ROGER BALL

\author{
Grasslands Division, DSIR, P. B., Palmerston North
}

\begin{abstract}
$4 \mathrm{~N}$ balance representative of intensive dairyfarming is presented, based on a dynamic model integrating information on $\mathrm{N}$ flows for this system. Losses of about $50 \%$ of $\mathrm{N}$ ingested by animals lead to a negative $\mathrm{N}$ balance with predicted annual losses of $40 \mathrm{~kg} \mathrm{~N} / \mathrm{ha}$. Addition of $100 \mathrm{~kg}$ fertiliser $\mathrm{N}$ is predicted to reduce the $\mathrm{N}$ deficit by $13 \mathrm{~kg} / \mathrm{ha}$, with increased leaching and lower clover fixation reducing the effectiveness of applied N. Increasing the level of utilisation from 70 to $75 \%$ of herbage produced, by increasing stocking rate, is predicted to increase annual losses to about $60 \mathrm{~kg} / \mathrm{ha}$. Additional losses from excreta and reduced cycling of dead plant material contribute to the increased deficit. The implication of losses of this order to farm productivity are discussed.
\end{abstract}

\section{INTRODUCTION}

Nitrogen $(\mathrm{N})$ is quantitatively the most important element derived by pasture plantsfrom soil. Even well managed pastures are subject to continual $\mathrm{N}$ stress during periods of active growth (Field and Ball, 1978), despite the fact that clovers can be independent of the soil for $\mathrm{N}$, by fixing $\mathrm{N} 2$ gas from the air. Because $\mathrm{N}$ relationships exert a profound influence on both yield and botanical composition of clover-based pastures, it is important that we understand management effects on $\mathrm{N}$ balances and flows in soil-plant-animal systems. In this paper we consider a $\mathrm{N}$ balance representative of intensive dairyfarming, based on studies at Palmerston North and elsewhere, and we investigate the effects of either an input of fertiliser $\mathrm{N}$ or increasing the level of utilisation on $\mathrm{N}$ flows and the $\mathrm{N}$ balance for this system.

\section{NITROGEN BALANCE}

Climax clover-based pastures are close to equilibrium annual $\mathrm{N}$ inputs being approximately equal to $\mathrm{N}$ outputs (Jackman, 1964). While small changes in total $\mathrm{N}$ stored in the soil can be measured over time intervals of several years (Ball, 1979), it is difficult to evaluate directly the relative importance of most of the flows of $\mathrm{N}$ in the ecosystem, However, parts of the $\mathrm{N}$ cycle have been investigated in many studies. We have developed a relatively simple dynamic model which enables us to integrate such information and so to quantify the various avenues of $\mathrm{N}$ movement (Field and Ball, 1980). 
The model considers the $\mathrm{N}$ balance in an intensively utilised dairyfarm: that is, one in which $70 \%$ of total herbage accumulation ( 15 . I tDM/ ha) is utilised, at an effective stocking rate of 3.1 cows/ha. Central to the model is an accounting of additions to and abstractions from the soil mineral $\mathrm{N}$ pool, together with the regulatory effect of mineral $\mathrm{N}$ availability on both grass/ clover balance and $\mathrm{N}$ uptake by clovers. On a daily basis, it calculates nett mineralisation, $\mathrm{N}$ flows from soil to plant, ingestion by grazing animals, excretion and associated losses, death of plant parts and losses from the soil mineral $\mathrm{N}$ pool. These daily flows can be summed into seasonal or annual movements.

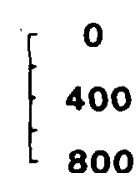

$\mathrm{kg} \mathrm{N} /$ ha

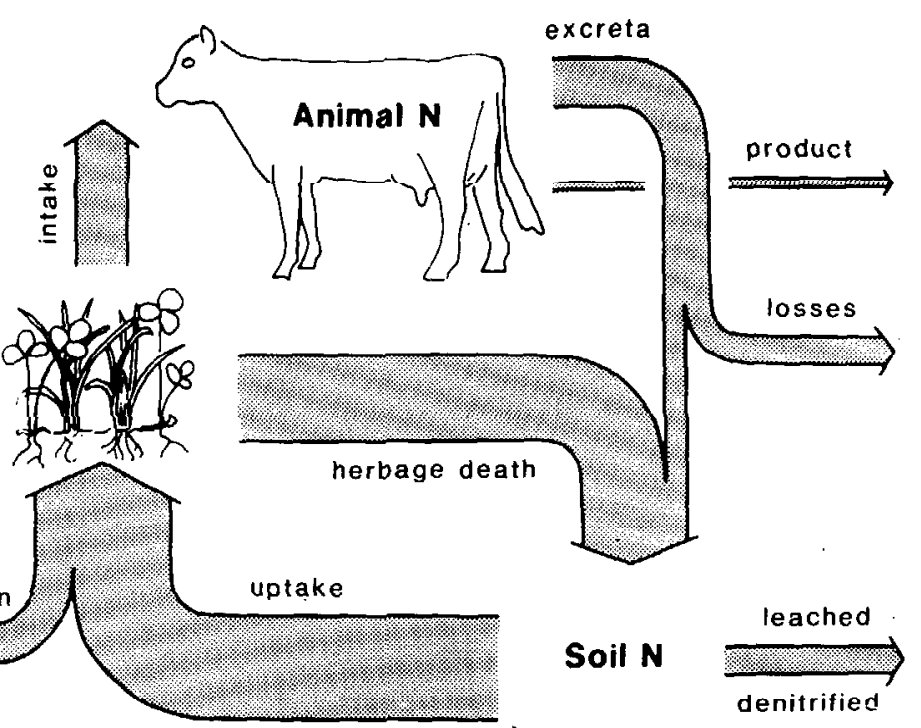

background

FIG. I: $N$ flows in an intensively utilised dairyfarm system: arrows drawn to scale.

Fig. 1 presents a simplified, annual cycle for $\mathrm{N}$ in such a dairyfarm. Plants take up $690 \mathrm{~kg} \mathrm{~N} /$ ha from soil mineral $\mathrm{N}$, mainly derived from mineralisation of soil organic matter totalling some $6000 \mathrm{~kg} \mathrm{~N} / \mathrm{ha}-20 \mathrm{~cm}$ depth. Biological $\mathrm{N}$ fixation by the clover-rhizobium symbiosis provides the major input of $\mathrm{N}$ to the system, with a small amount of background $\mathrm{N}$ added in rainwater and by non-symbiotic fixation (Ball, 1979). Nitrogen fixation meets little over half the $440 \mathrm{~kg} / \mathrm{ha}$ estimated as the requirements for clover growth (both above and below ground) annually. Grass and clover herbage $\mathrm{N}$ yields of 310 and $220 \mathrm{~kg}$ / ha respectively, fall within the range of values reported for Palmerston North (Brock and Hoglund, 1979).

Cycling within the system is dominated by $\mathrm{N}$ movement through plant growth, death and decay. Grass, at $92 \mathrm{~kg} / \mathrm{ha}$, contributes $17 \mathrm{~kg}$ more than clover to $\mathrm{N}$ in senesced herbage, calculated using published data for herbage 
longevity (Brougham 1958; Hunt and Brougham 1966; Hunt 1971). Clover stolon and clover and grass roots are assumed to be completely replaced annually (Hollowell, 1966), with a pattern of turnover derived from data of Caradus and Evans (1977). This gives a further 240 and $160 \mathrm{~kg} / \mathrm{ha}$ from clover and grass tissues, respectively.

Nitrogen not voided by the animals, calculated from relationships published by Henzell and Ross (1973), leaves the system as dairy production. This $14 \%$ of forage $\mathrm{N}$ yielded as product represents production levels of around $100 \mathrm{~kg}$ protein/ ha or about $140 \mathrm{~kg}$ milkfat/cow. One half of ingested $\mathrm{N}$ is eventually lost from farming system: by transfer to non-pasture areas (32 $\mathrm{kg} / \mathrm{ha})$, losses of urine $\mathrm{N}$ (140 kg/ ha) and from dung (6 kg/ ha). Losses from urine vary with season, according to the data of Ball and Keeney (198 I). The assumed importance of ammonia volatilization (44\% of urine $\mathrm{N}$ losses) is supported by recently published studies (Hogg, 1981; Catchpoole et a/., 1981). Nearly equal amounts of dung and urine $\mathrm{N}$ return to the soil $\mathrm{N}$ pool.

4 further avenue of $\mathrm{N}$ loss is through leaching of soil mineral $\mathrm{N}$ not directly associated with excreta (24 kg/ ha) and denitrification (47 kg/ ha).

Seasonally, soil organic $\mathrm{N}$ levels are depleted to the greatest extent during late spring-early summer (by $70 \mathrm{~kg} \mathrm{~N} / \mathrm{ha}$ ) and replenished during autumnwinter. However, total $\mathrm{N}$ in the system does not oscillate to the same degree. During the period of greatest soil $\mathrm{N}$ loss, $\mathrm{N}$ accumulates in clover stolon and herbage tissues, compensating for much of the change in soil $\mathrm{N}$ reserves. Overall, the balance is negative with an annual loss of $40 \mathrm{~kg} \mathrm{~N} /$ ha (Table I), or about $4 \%$ of the total $\mathrm{N}$ passing through the plant $\mathrm{N}$ pool. Clover fixation replenishes most of the losses from the system.

TABLE 1. NITROGEN FLOWS AND BALANCE IN MODEL DAIRYFARM SYSTEM (control) AND CHANGES INDUCED BY ADDITION OF $100 \mathrm{KG} / \mathrm{HA}$ FERTILISER N OR INCREASED UTILISATION.

\begin{tabular}{|c|c|c|c|}
\hline & control & $\begin{array}{c}\mathrm{kg} \mathrm{N} / \mathrm{ha} \\
\text { change } \\
\text { fertiliser } \mathrm{N}\end{array}$ & $\begin{array}{l}\text { from control } \\
75 \% \text { utilisation }\end{array}$ \\
\hline Clover fixation & 248 & -54 & -1 \\
\hline Mineralisation & 624 & +1 & -1 \\
\hline Plant uptake & 691 & +86 & +2 \\
\hline Animal intake & 369 & +19 & +29 \\
\hline Plant death/ decay & 573 & +13 & -28 \\
\hline Animal production & 50 & +2.1 & +4.4 \\
\hline Excreta losses & 182 & +8 & +15 \\
\hline Urine and dung recycled & 137 & +9 & +9 \\
\hline Denitrificatibn & 47 & - & \\
\hline Leaching & 24 & +23 & -1 \\
\hline Overall balance & 40 & +13 & -19 \\
\hline
\end{tabular}




\section{FERTILISER NITROGEN INPUTS}

The model was used to assess the influence of fertiliser N. 4 relatively small input of fertiliser $\mathrm{N}$ is predicted to have a positive effect on the $\mathrm{N}$ balance (Table I). Here it is assumed that $100 \mathrm{~kg}$ / ha of fertiliser $\mathrm{N}$, applied as equal splits in autumn and late winter, enters directly into the mineral $\mathrm{N}$ pool. Increased soil $\mathrm{N}$ availability allows a substantial increase in $\mathrm{N}$ uptake by grasises $(84 \mathrm{~kg} / \mathrm{ha}$ ). Total clover $\mathrm{N}$ (uptake + fixation) is reduced by $11 \%$, with soil-derived $\mathrm{N}$ substituting for $27 \mathrm{~kg} /$ ha of fixed $\mathrm{N}$. Further, the greater competitiveness of grasses under high $\mathrm{N}$ conditions reduces clover growth, and 'thus fixation, by another $26 \mathrm{~kg} / \mathrm{ha}$.

Two-thirds of the net increase in sward uptake of $30 \mathrm{~kg} / \mathrm{ha}$ is ingested by the animal, with attendant increases in production, losses and recycling of excreted $\mathrm{N}$. With utilisation maintained at $70 \%$ by increasing stocking rate to 3.2 cows/ ha, an additional $12 \mathrm{~kg} / \mathrm{ha}$ is also cycled through the decomposer network.

The increase obtained in product output, representing $18 \mathrm{~kg}$ milkfat, agrees closely with the response reported by Bryant (1980). This small response to $100 \mathrm{~kg} / \mathrm{ha}$ applied $\mathrm{N}$ highlights the need to be at or near a feed shortage for fertiliser $\mathrm{N}$ to provide a meaningful benefit. For example, with more cows achieving $75 \%$ utilisation, a further $5 \mathrm{~kg}$ product $\mathrm{N}$ should have resulted. Although fertiliser $\mathrm{N}$ can reduce management stress at lower stocking rates, it is of most benefit where it enables extra stock to be carried. Tactical applications can do this by increasing pasture production at times when feed deficits will occur at the higher stocking rate (Field and Ball, 1978).

\section{INCREASED UTILISATION}

As can be seen from Fig. 1, movement through the plant litter cycle to the decomposer network dominates the $\mathrm{N}$ cycle. This pathway is basically conservative, buffering the $\mathrm{N}$ balance and sustaining soil organic $\mathrm{N}$. The ratio of $\mathrm{N}$ passing through plant death and decay to that passing through the 'leaky' animal pathway exerts a major influence on the overall $\mathrm{N}$ balance of the system. This ratio is determined by the level of utilisation of herbage grown, which is a function of both stocking rate and forage conservation practices. For the purposes of this paper we have used our model to explore the likely results of increasing utilisation from 70 to $75 \%$ of predicted forage yield, through an increase in stocking rate.

The increased level of utilisation increases herbage $\mathrm{N}$ ingestion at the expense of the litter-decomposer pathway (Table 1). Increased utilisation was assumed to have no effect on plant uptake or clover growth and fixation. The increase in product, equivalent to $38 \mathrm{~kg}$ milkfat/ ha, is greater than the increase of $70 \mathrm{~kg}$ milkfat expected for an increase in stocking rate of $1 \mathrm{cow} / \mathrm{ha}$ (Bryant, 1980). Losses through excretion remain about $50 \%$ of increased intake, while a slightly greater proportion of $\mathrm{N}$ passes through the dung pathway. The different pattern of use of mineral $\mathrm{N}$ results in a smaller leaching loss, but the' increase in animal-related losses pushes the $\mathrm{N}$ balance to a deficit of $59 \mathrm{~kg} / \mathrm{ha}$, " 
or $6 \%$ of the total annual movement through the plant pool.

The more negative $\mathrm{N}$ balance predicted by the model supports a contention (Ball, 1979; Ball and Keeney, 1981) that intensive dairying systems may be exploiting soil organic $\mathrm{N}$ reserves. At $75 \%$ utilisation, depletion approaches $1 \%$ per annum of the soil total $\mathrm{N}$. However, this depletion may have a large effect on farm productivity. The "labile" (i.e. easily mineralised) fraction mainly comprises recently-added residues with a low carbon:nitrogen ratio. The annual flow of clover $\mathrm{N}$ into the soil organic $\mathrm{N}$ pool is about $300 \mathrm{~kg} / \mathrm{ha}$, with dung providing a further $70 \mathrm{~kg} / \mathrm{ha}$. Therefore this $1 \%$ deficit may represent about $16 \%$ of the readily degraded organic $\mathrm{N}$ formed each year. Continued deficits of this order should eventually lead to mounting $\mathrm{N}$ stress in the grass component; a swing to legume dominance and lower productivity from the sward in late winter-early spring. Thus, excessively high utilisation could lead to marked oscillation in legume content and herbage productivity, and could force a return to lower stocking rates unless recourse is taken to fertiliser $\mathrm{N}$ inputs.

\section{CONCLUSIONS}

Performance of this model has highlighted important features of $\mathrm{N}$ relationships in our intensively utilised dairyfarming systems.

1. Most of the $\mathrm{N}$ incorporated into plant tissues each year returns to the soil organic $\mathrm{N}$ pool. The soil decomposer network consumes about $1.5 \mathrm{~kg}$ plant $\mathrm{N}$ for every $\mathrm{kg}$ forage $\mathrm{N}$ eaten by cows.

2. The effective pathway for transfer of fixed $\mathrm{N}$ from clovers to grass associates is through the death and subsequent decay of clover plant parts; not, as previously believed, by ingestion and subsequent excretion through grazing animals.

3. Clover substitute almost half soil mineral $\mathrm{N}$ for $\mathrm{N}$ fixation in meeting their $\mathrm{N}$ requirements for growth.

4. Grazing animals are the major cause of $\mathrm{N}$ losses from the system. For every $\mathrm{kg} \mathrm{N}$ output in dairy products, a further $5 \mathrm{~kg} \mathrm{~N}$ is lost from the system. About $80 \%$ of these non-productive outgoings stem from the aggregation of excess dietary $\mathrm{N}$ into excreta, with subsequent losses from urine patches in particular.

5. More intensively utilised dairyfarms may be in negative $\mathrm{N}$ balance. Clovers must fix upwards of $350 \mathrm{~kg} \mathrm{~N} /$ ha each year simply to keep up with $\mathrm{N}$ losses.

It seems doubtful that this is achieved, especially during years of poor clover growth.

6. Recourse may have to be taken to fertiliser $\mathrm{N}$ inputs to maintain the $\mathrm{N}$ balance in more intensively farmed, clover-based systems, alternatively effective stocking rates may have to be reduced.

This model was prepared to quantify $\mathrm{N}$ relationships in an intensively utilised dairyfarming system in the lower North Island. Our notional dairyfarm carries a ryegrass-white clover sward, is situated on a free-draining soil from recent alluvium and enjoys "average" weather conditions for 
Palmerston North. Caution is needed in extrapolating to other areas the values and conclusions drawn. However, research on a heavier, poorly drained soil in Southland (Carran, 1978) indicates that the concepts and values recorded here are reasonably general.

\section{ACKNOWLEDGEMENTS}

Members of the staff of Grasslands Division for discussions leading to estimation of model parameters and contributions to evolution of model philosophy.

\section{REFERENCES}

Ball, R., 1979. Ph. D. Thesis, Massey University.

Ball, R.; Keeney, D. R.; Theobald, P. W.; Nes, P., 1980. Agron. J. 71: 309-14.

Ball, R.; Keeney, D. R., 1982. Proc. XIVth Int. Grassld. Cong. (Lexington, USA)In press.

Brock, J. L.; Hoglund, J. H., 1979. N.Z. J/ exp. Agric. 7: 27-9.

Brougham, R. W. , 1959. N.Z. Jl agric. Res. I: 707-18.

Bryant, A. M., 1980. Proc. N.Z. Grassld Ass. 42: 82-91.

Caradus, J. R.; Evans, P. S., 1977. N.Z. Il agric. Res. 20: 337-42.

Carran, R. A., 1978. Proc. N.Z. Grassid Ass. 40: 44-50.

Catchpoole, V. R.; Harper, L. A.; Myers, R. J. K., 1982. Proc. XIV th Int. Grassld Congr.

(Lexington, USA) In press.

Field, T. R. 0.; Ball, R.. 1978. Proc, Agron. Soc, N.Z. 8: 129-133.

Field, T. R. 0.; Ball, R., 1982. In "Nitrogen Balances for Terrestial Ecosystems in New Zealand" eds. P. W. Gandar and P. R. Ball. In press.

Henzell, E. F.; Ross, P. J., 1973. In "Chemistry and Biochemistry of Plants" eds. G. W. Butler and R. W. Bailey. Academic Press, New York.

Hogg, D. E., I98 I. N.Z. $J /$ exp. Agric. 9: 39.46.

Hoglund, J. H.; Crush, J. R.; Brock, J. L.; Ball, R.; Carran, R. A., 1979. Ibid. 7:45-51.

Hollowell, E. A., 1966. Pror. X th Int. Grass/d Congr. (Helsinki, Finland): 184-7.

Hunt, L. A.; Brougham, R. W., 1966. J. appl. Ecology 3: 21-8.

Hunt, W. F., 1970. Ibid. 7: 41-50.

Jackman, R. H., 1964, N. Z. $J l$ agric. Res. 7: 445-71. 